\title{
Nitrogenase Activity in Thermophilic Chemolithoautotrophic Bacteria in the Phylum Aquificae Isolated under Nitrogen-Fixing Conditions from Nakabusa Hot Springs
}

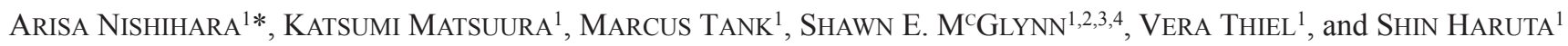 \\ ${ }^{1}$ Department of Biological Sciences, Tokyo Metropolitan University, Minami-Osawa, Hachioji, Tokyo 192-0397, Japan; ${ }^{2}$ Earth-Life \\ Science Institute, Tokyo Institute of Technology, Ookayama, Meguro-ku, Tokyo 152-8551, Japan; ${ }^{3}$ Biofunctional Catalyst Research \\ Team, RIKEN Center for Sustainable Resource Science, Wako-shi 351-0198, Japan; and ${ }^{4}$ Blue Marble Space Institute of Science, \\ Seattle, WA 98145-1561, USA
}

(Received March 16, 2018-Accepted August 12, 2018-Published online November 23, 2018)

The phylum Aquificae comprises chemolithoautotrophic thermophilic to hyperthermophilic bacteria, in which the nitrogenase reductase gene (nifH) has been reported. However, nitrogen-fixing activity has not yet been demonstrated in members of this deeply branching bacterial phylum. We isolated two thermophilic diazotrophic strains from chemosynthetic microbial communities in slightly alkaline hot springs $\left(\geq 70^{\circ} \mathrm{C}\right)$ in Nakabusa, Nagano Prefecture, Japan. A phylogenetic analysis based on $16 \mathrm{~S}$ rRNA genes identified these strains as members of the genus Hydrogenobacter within Aquificae. Their NifH sequences showed 96.5 and 97.4\% amino acid sequence identities to that from Hydrogenobacter thermophilus TK-6. Nitrogenase activity, measured by acetylene reduction, was confirmed in both strains at $70^{\circ} \mathrm{C}$. These novel strains grew under semi-aerobic conditions by using $\mathrm{CO}_{2}$ as the sole carbon source and $\mathrm{N}_{2}$ as the sole nitrogen source in media containing hydrogen and/or thiosulfate. To the best of our knowledge, this is the first demonstration of active nitrogen fixation in thermophilic bacteria at $70^{\circ} \mathrm{C}$ and in the phylum Aquificae.

Key words: nitrogen fixation, thermophile, Aquificales, nifH gene, hydrogen-oxidizing bacteria

The phylum Aquificae is a deeply branching bacterial phylum that contains chemolithoautotrophic thermophilic to hyperthermophilic bacteria. The phylum Aquificae consists of a single order, Aquificales, and three families, Aquificaceae, Hydrogenothermaceae, and Desulfurobacteriaceae, as well as Thermosulfidibacter takaii, a member of uncertain taxonomic affiliation within the phylum $(10,31)$. The complete genome sequences of nine Aquificae are available in the public database, and two of them, Hydrogenobacter thermophilus TK- $6^{\mathrm{T}}$ (WP 012963773) and Thermocrinis albus DSM 14484 ${ }^{\mathrm{T}}$ (WP_012991466) contain nifH genes encoding nitrogenase reductase, a key enzyme for biological nitrogen fixation (45, 48). Environmental putative nifH gene sequences that phylogenetically cluster with nifH sequences from isolated Aquificae strains have been obtained from various (hyper)thermophilic microbial communities $(7,8,13,22,29)$. However, nitrogenfixing activity has not been demonstrated in any members of the phylum Aquificae.

At Nakabusa hot springs in Japan, chemosynthetic microbial communities develop in slightly alkaline sulfidic hot springs with temperatures higher than $70^{\circ} \mathrm{C}$, similar to many other thermophilic terrestrial hot springs worldwide $(24-28,34,35$, 40, 43, 44, 46). In these communities, Aquificae are the dominant bacteria and are assumed to fix carbon and provide organic compounds as primary producers to the communities $(2,16)$. Despite low concentrations of nitrogen compounds, e.g., $\leq 6.1 \mu \mathrm{mol} \mathrm{L}{ }^{-1}$ of ammonium in the alkaline hot spring water at Nakabusa, high biomass production levels have been observed

\footnotetext{
* Corresponding author. E-mail: arisa.nishihara@gmail.com;
} Tel: +81-42-677-2581; Fax: +81-42-677-2559. in chemosynthetic microbial communities, and have sometimes been higher than those achieved by photosynthetic productivity $(12,16)$.

We previously reported nitrogen fixation activity at $70^{\circ} \mathrm{C}$ in chemosynthetic communities from Nakabusa hot springs, which was related to autotrophic sulfate-reducing metabolism (28). Subsequent molecular analyses targeting nifH revealed a high abundance of Aquificae-related putative nifH sequences, indicating members of Aquificae as potentially dominant diazotrophs in these communities (29).

In the present study, we isolated two thermophilic diazotrophic Aquificae from the chemosynthetic microbial communities in Nakabusa and demonstrated their nitrogenfixing abilities at $70^{\circ} \mathrm{C}$.

\section{Materials and Methods}

\section{Sample collection}

Microbial mats (pale-tan color) and streamers (pale-tan and gray color) were collected on March 29 and May 7, 2017 at [36 23'20"N $137^{\circ} 44^{\prime} 52^{\prime \prime E}$ (Wall Site) and [36 $23^{\prime} 33^{\prime \prime N}, 137^{\circ} 44^{\prime} 52^{\prime \prime E}$ (Stream Site), respectively, in Nakabusa hot springs, Japan. This hot spring water is slightly alkaline ( $\mathrm{pH} 8.0$ to 8.9$)$ and contains sulfide $(0.10$ to $\left.0.25 \mathrm{mmol} \mathrm{L}^{-1}\right)$ and small amounts of nitrogen compounds (5.0 to $6.1 \mu \mathrm{mol} \mathrm{L}-1$ of ammonium, and below detection limits of nitrate and nitrite), as previously described $(12,15,26,27)$. The samples collected in 30 -mL test-tubes filled with hot spring water were brought to the laboratory, stored at room temperature for up to $12 \mathrm{~d}$, and used for bacterial cultivation at $70^{\circ} \mathrm{C}$ within $12 \mathrm{~d}$.

\section{Cultivation of nitrogen-fixing bacteria}

Nitrogen compound-free ( $\mathrm{N}$-free) modified TK-6 medium (10, 11) was prepared by replacing $\left(\mathrm{NH}_{4}\right)_{2} \mathrm{SO}_{4}$ with $\mathrm{Na}_{2} \mathrm{~S}_{2} \mathrm{O}_{3}\left(1 \mathrm{~g} \mathrm{~L}^{-1}\right)$. $\mathrm{CO}_{2}$ gas was used as the sole carbon source in the medium. A total 
of $0.75 \mathrm{~mL}$ of a modified trace mineral solution was used per $\mathrm{L}$ medium (10), and the modified trace mineral solution was supplemented with $0.5 \mathrm{~g} \mathrm{Na}_{2}$-EDTA $2 \mathrm{H}_{2} \mathrm{O}$ and $0.1 \mathrm{~g} \mathrm{Na}_{2} \mathrm{SeO}_{4}\left(\mathrm{~L}^{-1}\right)$, while nitrilotriacetic acid, $\mathrm{H}_{2} \mathrm{SeO}_{3}$, and $\mathrm{KAl}\left(\mathrm{SO}_{4}\right)_{2} \cdot 12 \mathrm{H}_{2} \mathrm{O}$ were omitted. The $\mathrm{pH}$ of the medium was adjusted to 7.0 using $\mathrm{HCl}$ prior to autoclaving. Twenty milliliters of the medium was placed into a $120-\mathrm{mL}$ glass vial. The vial was sealed with a butyl rubber stopper and aluminum cap, and autoclaved after the gas phase was replaced with $\mathrm{N}_{2}: \mathrm{CO}_{2}(4: 1, \mathrm{v}: \mathrm{v})$. After autoclaving, $15-30 \%$ vol. $\mathrm{H}_{2}$ gas and $1-10 \%$ vol. $\mathrm{O}_{2}$ gas were aseptically added to the gas phase (described in detail below).

\section{Enrichment of nitrogen-fixing thermophilic bacteria}

Microbial mats and streamers were homogenized using an aseptic glass homogenizer. Two hundred microliters of the homogenized samples were inoculated into $20 \mathrm{~mL}$ of $\mathrm{N}$-free modified TK-6 medium and incubated at $70^{\circ} \mathrm{C}$ under static conditions in the presence of $30 \%$ vol. of $\mathrm{H}_{2}$ gas. One milliliter of each culture was subcultured 4 times every 1-2 weeks into fresh $\mathrm{N}$-free modified TK-6 medium for the enrichment of nitrogen-fixing bacteria under two conditions of 1 and $5 \%$ vol. $\mathrm{O}_{2}$ as well as $30 \%$ vol. of $\mathrm{H}_{2}$ gas in the headspace of the vials.

\section{Isolation of nitrogen-fixing thermophilic bacteria}

Solid medium of N-free modified TK-6 medium containing $0.8 \%$ (w/v) gellan gum (Wako, Osaka, Japan) was prepared in sealed vials as described above. A diluted enrichment culture was injected into the vials before cooling and then solidified. Different $\mathrm{O}_{2}$ concentrations $(1,5,8$, or $10 \%$ vol.) in the gas phase were applied for appropriate conditions to obtain visible colonies (Fig. 1) for isolation into an axenic culture. Visible colonies were picked up aerobically and repetitively subcultured at least three times in fresh medium until an axenic culture was achieved. Purity of the isolates was confirmed by phase-contrast microscopy observations and 16S rRNA gene sequencing.

\section{Testing the requirement for dinitrogen and oxygen for growth}

Bacterial isolates were pre-cultured in $\mathrm{N}$-free modified TK-6 medium in $70-\mathrm{mL}$ vials. The gas phase consisted of $\mathrm{N}_{2}: \mathrm{CO}_{2}: \mathrm{H}_{2}$ (4:1:2, v:v:v) with $5 \%$ vol. $\mathrm{O}_{2}$. One hundred microliters of the pre-culture solutions in the stationary phase of growth ([2.9 to $3.9] \times 10^{7}$ cells $\mathrm{mL}^{-1}$ ) were inoculated into $20 \mathrm{~mL}$ of $\mathrm{N}$-free modified TK-6 medium in 70-mL vials under a gas phase of either $\mathrm{N}_{2}: \mathrm{CO}_{2}: \mathrm{H}_{2}$ $(4: 1: 2, \mathrm{v}: \mathrm{v}: \mathrm{v})$ or $\mathrm{Ar}: \mathrm{CO}_{2}: \mathrm{H}_{2}(4: 1: 2, \mathrm{v}: \mathrm{v}: \mathrm{v})$ with 1,5 , or $10 \%$ vol. $\mathrm{O}_{2}$. Vials were incubated at $70^{\circ} \mathrm{C}$ and shaken by hand once a day for $5 \mathrm{~s}$. When indicated, $2 \mathrm{mmol} \mathrm{L}^{-1}$ of $\mathrm{NH}_{4} \mathrm{Cl}$ was added to the medium. Bacterial growth was assessed by cell counting using a phase-contrast microscope (AXIO Imager A2; Carl Zeiss, Oberkochen, Germany) and a counting chamber (SLGC, Saitama, Japan). The experiment was conducted in triplicate.
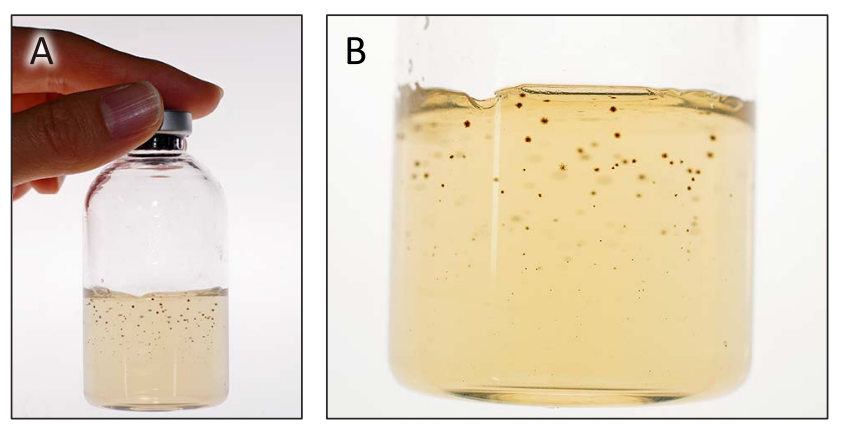

Fig. 1. Photo images showing colony formation in a solidified medium. These images showed isolated strain 1-6 growing in a medium solidified with gellan gum. A, Dark-colored colonies formed in $30 \mathrm{~mL}$ of solidified medium in a $70-\mathrm{mL}$ vial; $\mathrm{B}$, Magnified portion of the vial.
DNA extraction and phylogenetic analysis based on $16 S$ rRNA and nifH genes

DNA was isolated from bacterial cells following a combined protocol of mechanical disruption (bead beating) and chloroform phenol extraction, as described by Noll et al. (30). The 16S rRNA genes and putative nifH genes of bacterial isolates were amplified using the 16S rRNA gene primers 27F2/1492R2 $(20,21)$ and nifH gene primers PolF/PolR (33) under the standard PCR conditions given in the respective references. PCR was performed using ExTaq polymerase (Takara, Kusatsu, Japan) as described previously (28, 29). Purified PCR products were prepared and sequenced using BigDye terminator kit v3.1 on an ABI 3130 Genetic Analyzer (Applied Biosystems, Foster city, CA, USA) according to the standard protocol. nifH gene sequences were translated into amino acid sequences using the standard code in MEGA7 (19). The deduced NifH sequences were confirmed to contain one required residue, Cys 97 (protein numbering for NifH in Azotobacter vinelandii; PCR products were of insufficient lengths to contain both Cys 97 and Cys 132 ), which is a $4 \mathrm{Fe}-4 \mathrm{~S}$ iron sulfur cluster ligating cysteine, and were used to construct a phylogenetic tree as previously reported (9, 29). NifH and 16S rRNA gene sequences were aligned in ClustalW with default settings implemented in MEGA7 (19). Phylogenetic trees for the 16S rRNA gene and NifH sequences were reconstructed using the Maximum Likelihood method with the Tamura-Nei model in MEGA7 (19) and the WAG model in the ARB program package (23), respectively. The robustness of the tree topologies was tested with 500 (for 16S rRNA) or 100 (for NifH) bootstrap replicates.

\section{Acetylene reduction assay}

Nitrogenase activity was measured using the acetylene reduction method $(1,39)$. The production of ethylene from acetylene was quantified using a GC-2014 gas chromatograph (Shimadzu, Kyoto, Japan) equipped with an 80/100 Porapak T (GL Science, Tokyo, Japan) column. Three hundred microliters of the headspace gas of each bacterial culture vial was injected once into the column. A flame ionization detector was used with nitrogen as the carrier gas. The run conditions of the injection and detection port temperatures were $100^{\circ} \mathrm{C}$ and $50^{\circ} \mathrm{C}$, respectively. Ethylene production was calculated by a standard curve generated from standard ethylene gas (GL Science).

\section{Sample preparation for the acetylene reduction assay}

The nitrogen-fixing activities of the isolates in solid media were tested as follows: $300 \mu \mathrm{L}$ of culture solutions were injected into $8 \mathrm{~mL}$ of $\mathrm{N}$-free modified TK- 6 medium containing $0.8 \%$ gellan gum and $\mathrm{N}_{2}: \mathrm{CO}_{2}(4: 1, \mathrm{v}: \mathrm{v})$ gas in the headspace of 20 -mL sealed vials. $\mathrm{H}_{2}$ ( $25 \%$ vol.) and $\mathrm{O}_{2}$ (1 to $10 \%$ vol.) were added to the headspace prior to the inoculation. After incubation at room temperature overnight to solidify the medium, vials were incubated at $70^{\circ} \mathrm{C}$ for $3 \mathrm{~d}$ with the addition of $15 \%$ vol. of $99.99 \%$ acetylene gas (Tatsuoka, Chiba, Japan). This experiment was conducted in duplicate.

To assess acetylene reduction in liquid medium, bacteria were cultivated for $2 \mathrm{~d}$ in $\mathrm{N}$-free modified TK-6 medium under $\mathrm{N}_{2}: \mathrm{H}_{2}: \mathrm{CO}_{2}$ $(5: 4: 1, \mathrm{v}: \mathrm{v}: \mathrm{v})$ and the addition of $5 \%$ vol. $\mathrm{O}_{2}$. Two milliliters of the cultures were placed into a $7-\mathrm{mL}$ sealed vial. The headspace was replaced with $\mathrm{Ar}: \mathrm{H}_{2}: \mathrm{CO}_{2}$ (5:4:1, v:v:v). $\mathrm{NH}_{4} \mathrm{Cl}\left(2 \mathrm{mmol} \mathrm{L}^{-1}\right)$ was added when indicated.

After 10 -min pre-incubation at $70^{\circ} \mathrm{C}$ in a water bath, $15 \%$ vol. of $99.99 \%$ acetylene gas (Tatsuoka) was injected into the headspace. After 3-h incubation at $70^{\circ} \mathrm{C}, 200 \mu \mathrm{L}$ of $37 \%$ formaldehyde was added to stop the reaction producing ethylene. Examination under each condition was conducted in triplicate.

A negative control without bacteria was prepared to estimate any ethylene background generated from non-biological sources.

\section{Influence of molybdate on acetylene reduction}

Bacteria were cultivated for $2 \mathrm{~d}$ in liquid $\mathrm{N}$-free modified TK-6 medium under the $\mathrm{N}_{2}: \mathrm{H}_{2}: \mathrm{CO}_{2}(5: 4: 1, \mathrm{v}: \mathrm{v}: \mathrm{v})$ or $\mathrm{N}_{2}: \mathrm{CO}_{2}(4: 1, \mathrm{v}: \mathrm{v})$ gas 
phase with the addition of $5 \%$ vol. $\mathrm{O}_{2}$. Two milliliters of each culture was placed into a $7-\mathrm{mL}$ sealed vial. The headspace was replaced with $\mathrm{Ar}: \mathrm{H}_{2}: \mathrm{CO}_{2}(5: 4: 1, \mathrm{v}: \mathrm{v}: \mathrm{v})$ with $\mathrm{O}_{2}\left(5 \%\right.$ vol.) or $\mathrm{Ar}: \mathrm{CO}_{2}(9: 1$, $\mathrm{v}: \mathrm{v})$, respectively. A total of $20 \mathrm{mmol} \mathrm{L}^{-1}$ of sodium molybdate was added when indicated. Sample preparation for the acetylene reduction assay was the same as that described above.

\section{Nucleotide sequence accession numbers}

16S rRNA and nifH gene sequences were deposited in DDBJ/ EMBL/GenBank with the accession numbers LC375847 (strain 1-6) and LC375848 (strain 2-18) for the 16S rRNA gene and LC375850 (strain 1-6) and LC375849 (strain 2-18) for the nifH gene.

\section{Results}

\section{Isolation of aerobic nitrogen-fixing bacteria}

After homogenization, pale-tan microbial mats and two types of streamers (pale-tan and grayish) were cultivated under diazotrophic conditions in a $\mathrm{N}_{2}: \mathrm{CO}_{2}: \mathrm{H}_{2}: \mathrm{O}_{2}$ atmosphere. After repetitive cultivation, bacterial growth was observed in all cultures containing both $1 \%$ and $5 \%$ vol. $\mathrm{O}_{2}$ in the headspace. The cultures were transferred into solid media under 1 to $10 \%$ vol. $\mathrm{O}_{2}$ and visible colonies were obtained in all cultures. Twenty-seven colonies were selected, purified, and used in the acetylene reduction assay tests: 14, 11, 1, and 1 isolates were obtained from the cultures with $1,5,8$, and $10 \%$ vol. $\mathrm{O}_{2}$, respectively (Fig. 1). In seven out of the 27 isolated samples, ethylene was clearly produced in acetylene reduction assays under a $\mathrm{N}_{2}: \mathrm{CO}_{2}: \mathrm{H}_{2}: \mathrm{O}_{2}$ atmosphere (data not shown), indicating that these seven isolates exhibited nitrogen-fixing abilities under the conditions tested. Based on 16S rRNA gene sequence analysis, the seven isolates were classified into two phylotypes; six sequences showed $100 \%$ nucleotide sequence identity to one another. The 16S rRNA gene sequences of these six strains were found in all samples; pale-tan microbial mats (four isolates), pale-tan streamers (one isolate), and gray streamers (two isolates). The representative isolate, strain 1-6, obtained from pale-tan mats with $5 \%$ vol. $\mathrm{O}_{2}$ in the vial headspace, was used for further analyses. Strain 2-18 was isolated from a gray streamer at 5\% vol. $\mathrm{O}_{2}$.
The results of the phylogenetic analysis of $16 \mathrm{~S}$ rRNA genes indicated that both isolates were closely related to species of the genera Hydrogenobacter and Thermocrinis (Fig. 2). A BLAST search supported this affiliation, with the closest cultivated relatives of strain 1-6 being Hydrogenobacter sp. GV4-1 (4) with 99.9\% identity and H. subterraneus HGP1 ${ }^{\mathrm{T}}$ (42) with $98.7 \%$ identity, and with the closest cultivated relative of strain 2-18 being $H$. hydrogenophilus DSM $2913^{\mathrm{T}}(6,18)$ with $97.6 \%$ identity. The two isolates shared $95.3 \% 16 \mathrm{~S}$ rRNA gene nucleotide identity with each other, indicating that they are representatives of two different species within the genus Hydrogenobacter.

\section{nifH sequences of isolates}

Putative nifH fragments were successfully amplified by PCR from the seven isolates and their DNA sequences were elucidated. The nifH gene sequences from the isolates were classified into two phylotypes showing the same relationship as that based on 16S rRNA gene sequences. As shown in Fig. 3 , the deduced NifH sequences of strains 1-6 and 2-18 clustered with $H$. thermophilus TK-6 ${ }^{\mathrm{T}}$ and T. albus DSM $14484^{\mathrm{T}}$, as well as environmental clones from microbial mats and streamers from Nakabusa (29), from hot spring sediments in Yellowstone National Park, and from Boiling Springs Lake water in Lassen Volcanic National Park, USA (7, 8, 22, 36). The NifH sequences of strains 1-6 and 2-18 showed $96.5 \%$ and $97.4 \%$ amino acid sequence identities, respectively, to that of $H$. thermophilus TK-6 ${ }^{\mathrm{T}}$ (WP 012963773). The two isolates shared $96.6 \% \mathrm{NifH}$ sequence identity with each other.

\section{Growth under nitrogen-fixing conditions and acetylene reduction activity of isolates}

Diazotrophic growth was examined to confirm the nitrogenfixing abilities of strains 1-6 and 2-18. These strains were cultivated in nitrogen-free liquid medium under $\mathrm{Ar}: \mathrm{H}_{2}: \mathrm{CO}_{2}$ or $\mathrm{N}_{2}: \mathrm{H}_{2}: \mathrm{CO}_{2}$ with $5 \%$ vol. of $\mathrm{O}_{2}$ (Fig. $4 \mathrm{a}$ and c). Both strains showed a small increase in cell numbers after $1.5 \mathrm{~d}$ of cultivation under nitrogen-free conditions (argon atmosphere, Fig. 4a

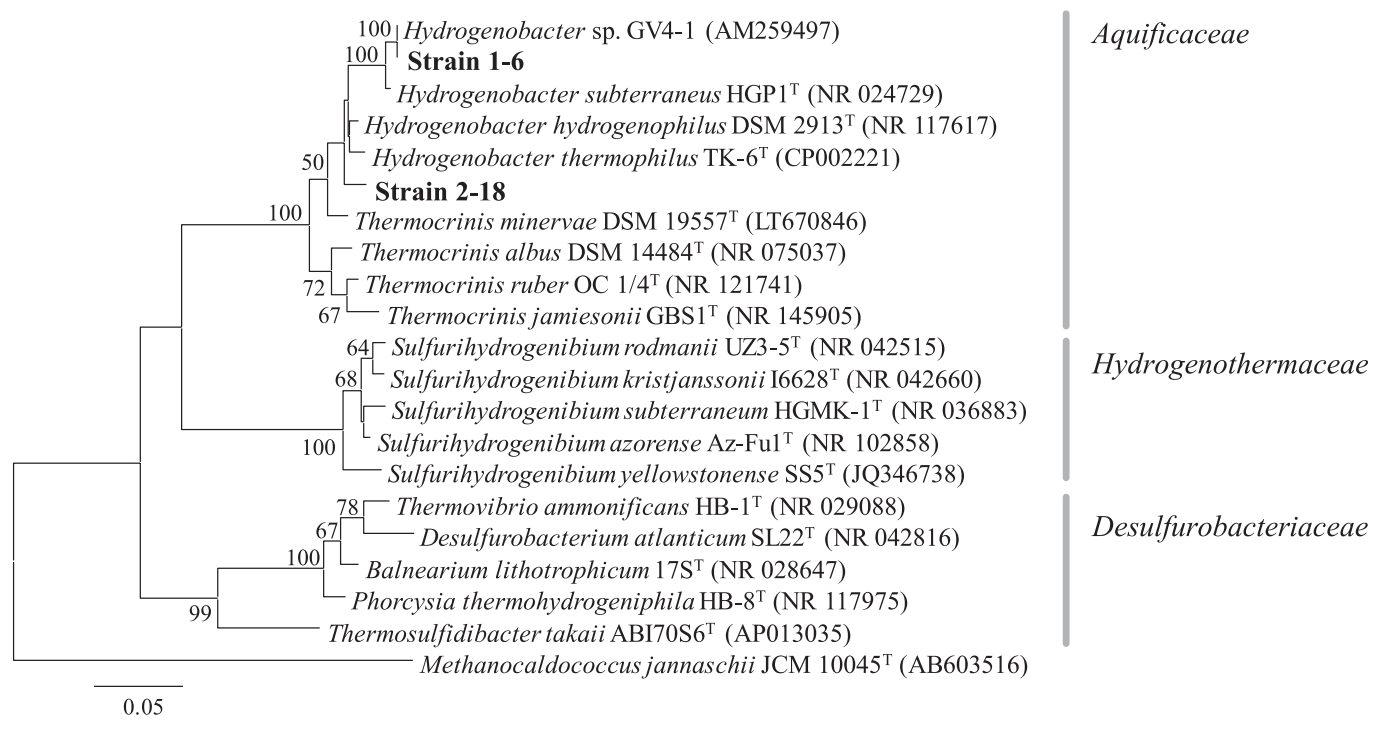

Fig. 2. A molecular phylogenetic tree by the maximum-likelihood method based on 16S rRNA gene sequences of isolated strains 1-6 and 2-18 (shown in bold), with close relatives in the phylum Aquificae. Bootstrap values higher than 50 are shown. The scale bar represents a substitution rate of 5 nucleotides per 100 nucleotides. 


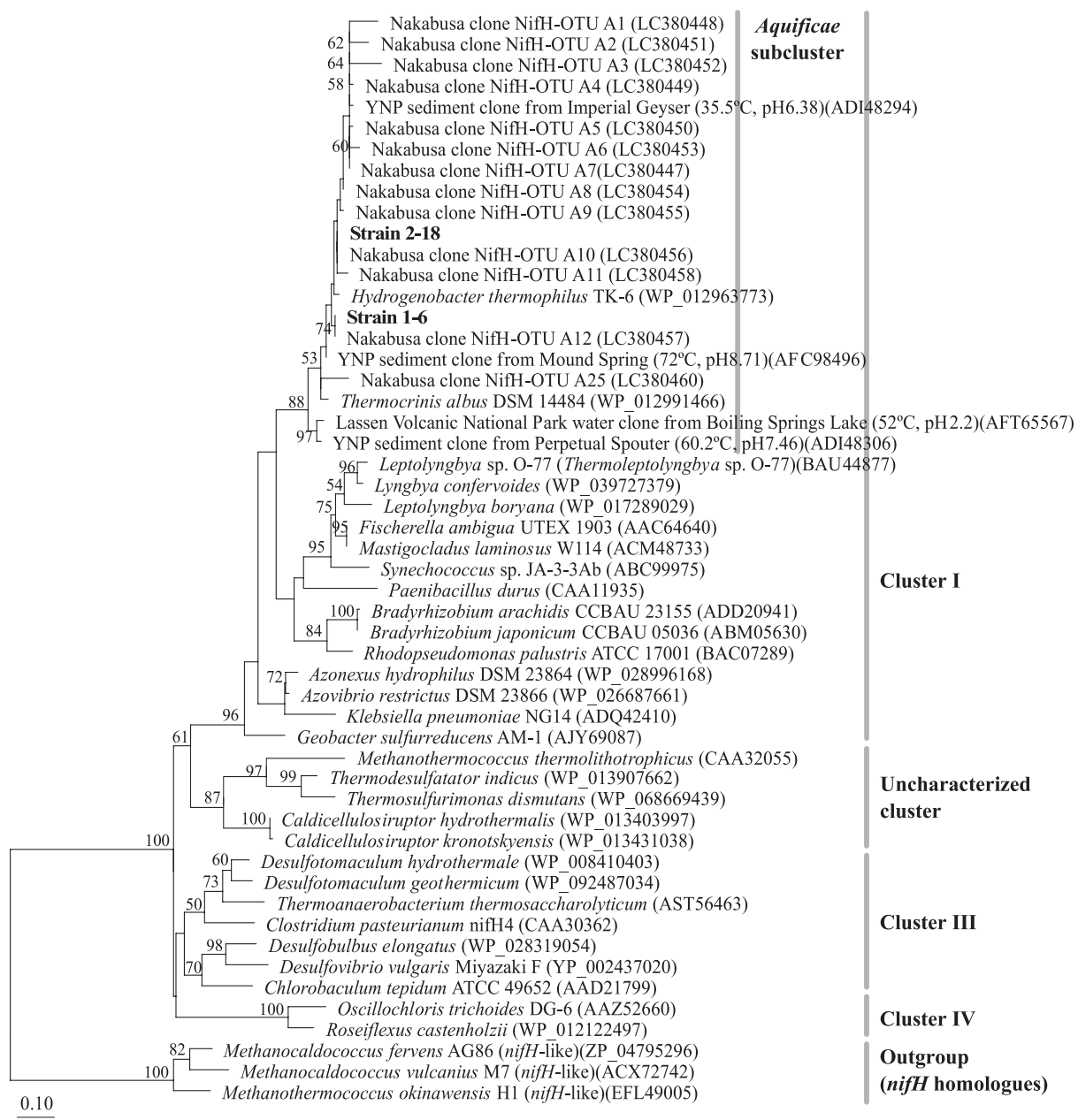

Fig. 3. Positions of NifH amino acid sequences of strains 1-6 and 2-18 (shown in bold) and closely related sequences in a maximum-likelihood inferred phylogenetic tree. YNP, Yellowstone National Park. Bootstrap values higher than 50 are shown. The scale bar represents 10 amino acid substitutions per 100 amino acids. Environmental clones from Nakabusa hot springs $\left(72-77^{\circ} \mathrm{C}, \mathrm{pH} 8.5-8.9\right)$ are shown in the Aquificae subcluster (29). NifH clusters defined by Zehr et al. are also shown (47).
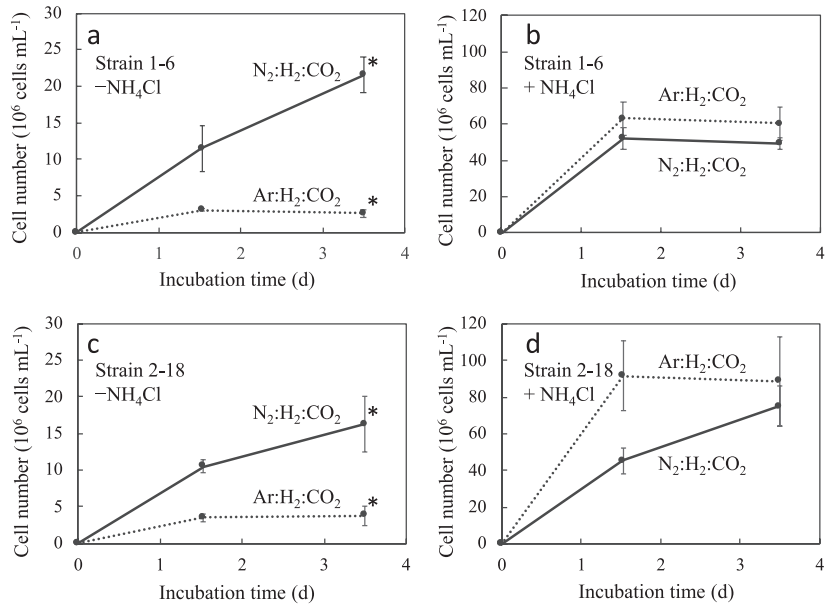

Fig. 4. Growth of strains 1-6 (a) (b) and 2-18 (c) (d) under $\mathrm{N}_{2}$ and argon atmospheres. Strains 1-6 and 2-18 were cultivated without $\mathrm{NH}_{4} \mathrm{Cl}$ (a) (c) or with $2 \mathrm{mmol} \mathrm{L}^{-1}$ of $\mathrm{NH}_{4} \mathrm{Cl}$ (b) (d) under the gas phase of $\mathrm{N}_{2}: \mathrm{H}_{2}: \mathrm{CO}_{2}(5: 4: 1)$ or Ar: $\mathrm{H}_{2}: \mathrm{CO}_{2}(5: 4: 1)$ with $5 \%$ oxygen. Cell numbers in the culture solution were counted under a microscope using a counting chamber (SLGC). Error bars represent the standard deviation of three replicates. An asterisk represents samples with significant differences (Student's $t$-test, $P<0.05$ ) between bacterial growths on day 3.5 under the gas phase of $\mathrm{N}_{2}: \mathrm{H}_{2}: \mathrm{CO}_{2}(5: 4: 1)$ or $\mathrm{Ar}: \mathrm{H}_{2}: \mathrm{CO}_{2}(5: 4: 1)$ with $5 \%$ oxygen. and c), and this may have been due to the small amounts of nitrogen compounds derived from the pre-culture; however, no further growth was observed. In contrast, under the $\mathrm{N}_{2}$ gas atmosphere, cell numbers continuously increased and reached $21.5 \pm 1.21 \times 10^{6}$ cells $\mathrm{mL}^{-1}$ for strain $1-6$ and $14.6 \pm 3.44 \times 10^{6}$ cells $\mathrm{mL}^{-1}$ for strain $2-18$ after $3.5 \mathrm{~d}$ of cultivation (Fig. 4a and c). The cell densities of strains 1-6 and 2-18 were 9.2- and 4.2-fold higher, respectively, under the nitrogen atmosphere than under the argon atmosphere. No marked differences in final cell densities (after $3.5 \mathrm{~d}$ of cultivation) were observed in the presence or absence of $\mathrm{N}_{2}$ in medium containing $\mathrm{NH}_{4} \mathrm{Cl}(P$ values $>0.05)$ (Fig. $4 \mathrm{~b}$ and d).

The nitrogenase activities of both strains were observed at $70^{\circ} \mathrm{C}$, as shown in Fig. $5 ; 46.5 \pm 8.54$ pmol $_{2} \mathrm{H}_{4} \times 10^{6}$ cells $^{-1} \mathrm{~h}^{-1}$ in strain 1-6 and $16.6 \pm 7.51$ pmol $\mathrm{C}_{2} \mathrm{H}_{4} \times 10^{6}$ cells $^{-1} \mathrm{~h}^{-1}$ in strain 2-18 in nitrogen-free medium with $5 \%$ vol. of $\mathrm{O}_{2}$. Nitrogenase activity in the presence of $2 \mathrm{mmol} \mathrm{L}^{-1} \mathrm{NH}_{4} \mathrm{Cl}$ in the acetylene reduction assay was observed in both isolates, but was lower than that in the absence of $\mathrm{NH}_{4} \mathrm{Cl}(P$ values $<0.05$ ), showing $7.01 \pm 2.23$ pmol $_{2} \mathrm{H}_{4} \times 10^{6}$ cells $^{-1} \mathrm{~h}^{-1}$ in strain 1-6 and 3.37 \pm 2.10 pmol $_{2} \mathrm{H}_{4} \times 10^{6}$ cells $^{-1} \mathrm{~h}^{-1}$ in strain 2-18. 


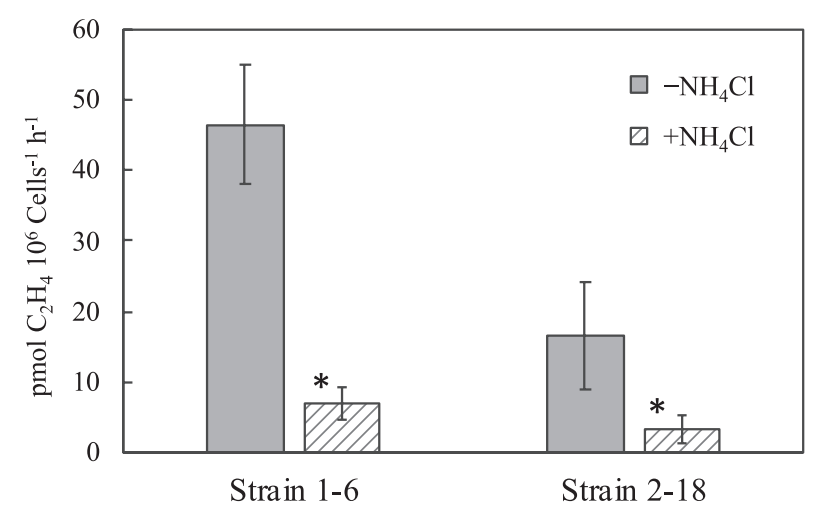

Fig. 5. Acetylene reduction activities of strains $1-6$ and 2-18 in the absence and presence of $\mathrm{NH}_{4} \mathrm{Cl}$. Strains 1-6 and 2-18 were cultivated in $\mathrm{N}$-free modified TK-6 medium under the gas phase of $\mathrm{N}_{2}: \mathrm{H}_{2}: \mathrm{CO}_{2}(5: 4: 1)$ with $5 \%$ oxygen for $2 \mathrm{~d}$. Ethylene production was measured under $\mathrm{Ar}: \mathrm{H}_{2}: \mathrm{CO}_{2}(5: 4: 1)$ with $5 \%$ vol. oxygen after a 3 -h incubation at $70^{\circ} \mathrm{C}$. Error bars represent the standard deviation of three replicates. An asterisk represents samples with significant differences (Student's $t$-test, $P<0.05$ ) between without $\mathrm{NH}_{4} \mathrm{Cl}\left(-\mathrm{NH}_{4} \mathrm{Cl}\right)$ and with $\mathrm{NH}_{4} \mathrm{Cl}\left(+\mathrm{NH}_{4} \mathrm{Cl}\right)$ in the 3-h incubation for the measurement of ethylene production.

\section{Dependence of growth on oxygen concentrations}

To examine the optimal $\mathrm{O}_{2}$ concentrations for growth under nitrogen-fixing conditions, growth under different initial concentrations of $\mathrm{O}_{2}$ was compared in the presence of both thiosulfate and $\mathrm{H}_{2}$. As shown in Fig. 6a, strain 1-6 showed faster growth at $10 \%$ vol. $\mathrm{O}_{2}$ than at 1 and $5 \%$ vol. $\mathrm{O}_{2}$; however, initial growth for $1.5 \mathrm{~d}$ was similar. In contrast, in Fig. $6 \mathrm{c}$ for strain $2-18$, growth was not observed at $10 \%$ vol. $\mathrm{O}_{2}$, but was better at $5 \%$ vol. $\mathrm{O}_{2}$ than at $1 \%$ vol. $\mathrm{O}_{2}$. In the presence of $\mathrm{NH}_{4} \mathrm{Cl}$, growth at $10 \% \mathrm{O}_{2}$ was better than under the other conditions for both strains (Fig. 6b and d). The semi-aerobic growth of both strains was also observed not only under conditions containing both thiosulfate and hydrogen, but also under conditions in which thiosulfate or hydrogen was the sole electron donor (data not shown).

\section{Effects of molybdate on nitrogenase activity}

We previously reported that the anaerobic nitrogenase activities of chemosynthetic thermophilic microbial mats and
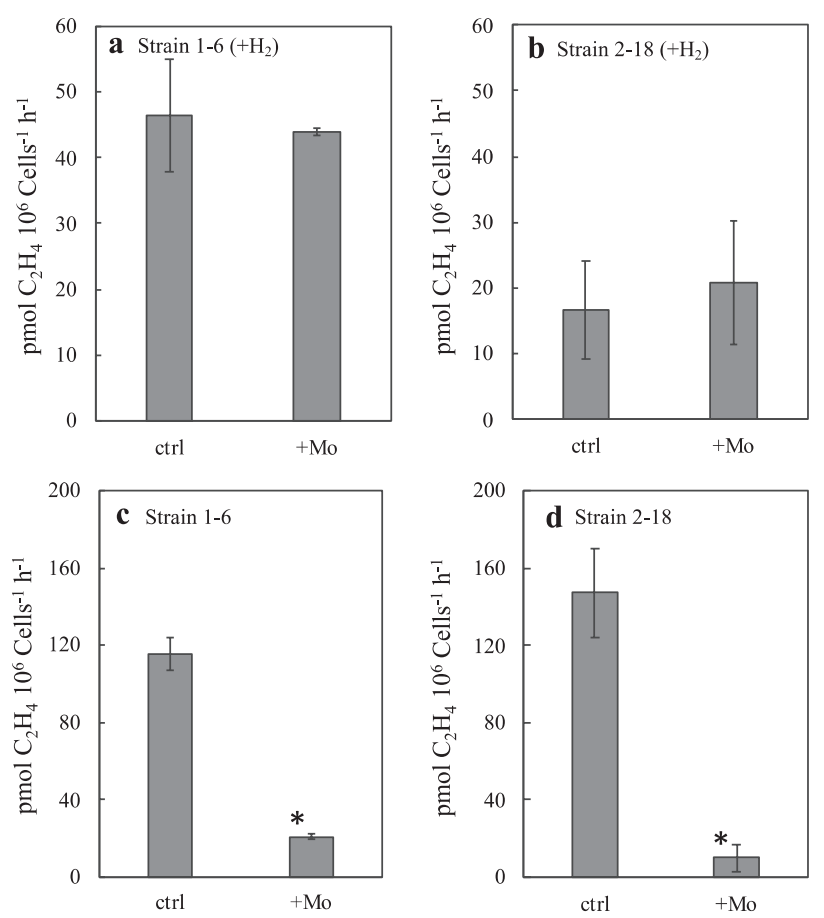

Fig. 7. Acetylene reduction activities of strains 1-6 (a) (c) and 2-18 (b) (d) in the presence and absence of molybdate ( + Mo). The column for the control ("ctrl") shows the same data as that shown for " $-\mathrm{NH}_{4} \mathrm{Cl}$ " in Fig. 4. Strains 1-6 and 2-18 were cultivated in N-free modified TK-6 medium containing thiosulfate under the gas phase of $\mathrm{N}_{2}: \mathrm{H}_{2}: \mathrm{CO}_{2}(5: 4: 1)$ for (a) (b) or $\mathrm{N}_{2}: \mathrm{CO}_{2}$ (4:1) for (c) (d) with 5\% vol. oxygen. Ethylene production by cultures was measured under $\mathrm{Ar}: \mathrm{H}_{2}: \mathrm{CO}_{2}(5: 4: 1)$ with $5 \%$ vol. oxygen (a) (b) or $\mathrm{Ar}^{-} \mathrm{CO}_{2}$ (9:1) without oxygen (c) (d) during a 3-h incubation at $70^{\circ} \mathrm{C}$. Error bars represent the standard deviation of three replicates. An asterisk represents samples with significant differences (Student's $t$-test, $P<0.05$ ) between without molybdate (ctrl) and with molybdate $(+\mathrm{Mo})$ in a $3-\mathrm{h}$ incubation for the measurement of ethylene production.

streamers in Nakabusa were mostly suppressed by molybdate (28), an inhibitor of dissimilatory sulfate reduction and other reactions involving sulfate adenylyltransferase (ATP sulfurylase) (32). The effects of molybdate on the activities of strain 1-6 and 2-18 were examined using 2-d pre-cultivated cultures under $5 \%$ vol. $\mathrm{O}_{2}$ (Fig. 7). The acetylene reduction
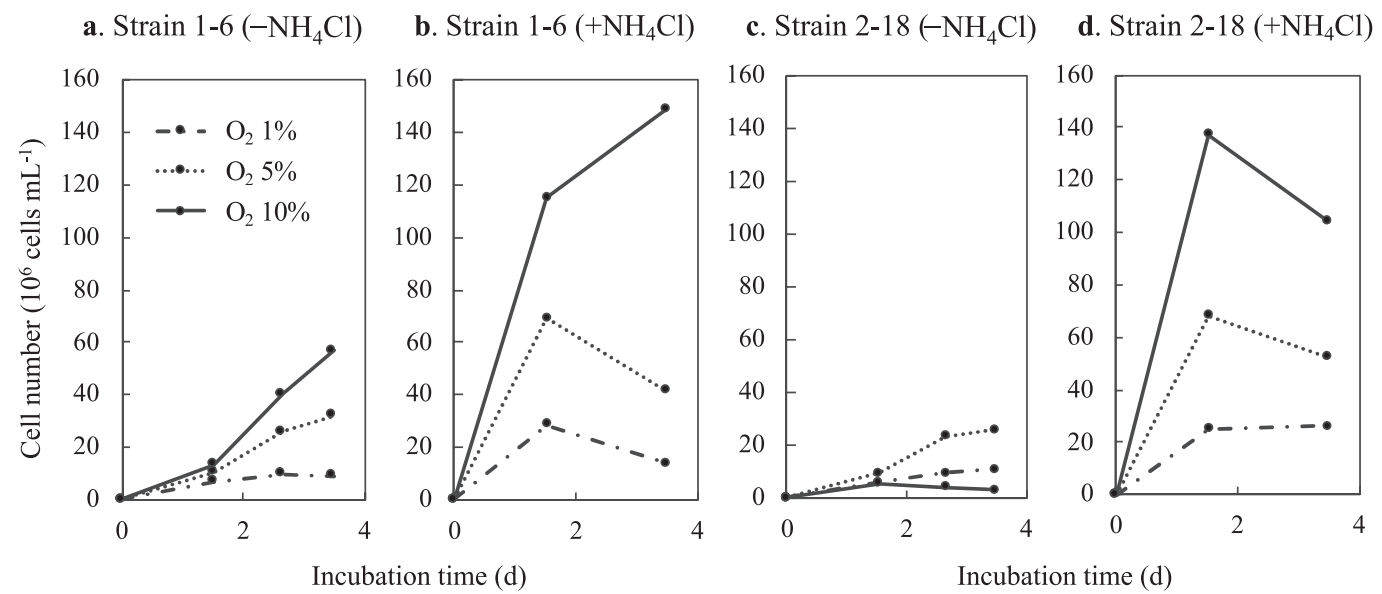

Fig. 6. Growth of strains 1-6 (a) (b) and 2-18 (c) (d) at different $\mathrm{O}_{2}$ concentrations. Strains 1-6 and 2-18 were cultivated without $\mathrm{NH}_{4} \mathrm{Cl}(\mathrm{a})(\mathrm{c})$ or with $2 \mathrm{mmol} \mathrm{L}^{-1}$ of $\mathrm{NH}_{4} \mathrm{Cl}$ (b) (d) under the gas phase of $\mathrm{N}_{2}: \mathrm{H}_{2}: \mathrm{CO}_{2}(5: 4: 1)$ with 1, 5, and $10 \%$ vol. oxygen. Cell numbers in the culture suspension were counted under a microscope. Only one representative replicate (of three) are shown for each condition. 
activities of these strains in the presence of both thiosulfate and $\mathrm{H}_{2}$ under $5 \%$ vol. $\mathrm{O}_{2}$ were not inhibited by the addition of molybdate at a final concentration of $20 \mathrm{mmol} \mathrm{L}^{-1}(P$ values $>0.05$ ) (Fig. 7a and b). On the other hand, these activities in the absence of $\mathrm{H}_{2}$ and $\mathrm{O}_{2}$ during activity measurements for $3 \mathrm{~h}$ were markedly inhibited by molybdate in both strains in cells that had been pre-cultivated with thiosulfate and $5 \%$ vol. $\mathrm{O}_{2}$ without $\mathrm{H}_{2}(P$ values $<0.05)$ (Fig. 7c and d).

\section{Discussion}

In the present study, seven strains and two distinct phylotypes of aerobic thermophilic chemolithoautotrophic nitrogen-fixing bacteria in the phylum Aquificae were isolated from Nakabusa hot springs, Japan. The $\mathrm{N}_{2}$-fixing capability of two novel strains in the phylum Aquificae was demonstrated by positive acetylene reduction activities and diazotrophic growth. Genome analyses indicated that two species of bacteria in Aquificae, $H$. thermophilus TK-6 ${ }^{\mathrm{T}}$ (WP_012963773) and T. albus DSM 14484 ${ }^{\mathrm{T}}$ (WP_012991466), possessed putative nifH genes, whereas their active nitrogen-fixing abilities have never been demonstrated. Kawasumi et al. reported that $H$. thermophilus TK-6 did not grow using nitrogen gas as a sole nitrogen source (14). Consistent with these findings, we found that $H$. thermophilus TK-6 (kindly provided by Dr. H. Arai) did not exhibit nitrogenfixing activity under the same conditions tested in the present study (data not shown). The nitrogen-fixing activities and diazotrophic growth of these novel isolates were observed at $70^{\circ} \mathrm{C}$. Prior to the present study, the maximum temperature observed for active nitrogen fixation by bacteria was $63.4^{\circ} \mathrm{C}$, as demonstrated in cyanobacteria from hot springs $(37,38)$.

The characteristics of nitrogenase activity in isolates differed from that previously reported for the chemosynthetic microbial communities of Nakabusa hot springs (28). Nitrogenase activities measured in communities under anaerobic conditions were suppressed by more than $95.5 \%$ by molybdate (an inhibitor of sulfate reduction and thiosulfate disproportionation $[5,17$, 32]). These communities also required $\mathrm{H}_{2}, \mathrm{CO}_{2}$, and sulfate (not thiosulfate) for their nitrogenase activities, suggesting that nitrogenase activity is associated with anaerobic autotrophic sulfate reduction in microbial communities. In contrast, the isolates showed nitrogenase activity with thiosulfate, which was inhibited by molybdate only under anaerobic (thiosulfate disproportionating) conditions. Therefore, the isolates may not be responsible for the previously measured nitrogenase activity (28). We previously analyzed putative nifH environmental clone sequences in chemosynthetic microbial communities at Nakabusa hot springs (29). The most abundant operational taxonomic units of nifH environmental clone sequences were related to Aquificae and the genus Caldicellulosiruptor in the phylum Firmicutes (29). The NifH sequences of both of the strains isolated in the present study have already been detected in environmental samples from Nakabusa hot springs (Fig. 3 ). Furthermore, closely related putative nifH sequences have been obtained from thermophilic environments in metagenome studies conducted on samples from Yellowstone National Park (USA), and the findings indicated the global distribution of nitrogen-fixing Hydrogenobacter in thermal environments $(7,8,22,36)$.

In addition to nifH genes, $16 \mathrm{~S}$ rRNA gene amplicon sequences closely related to those of strain 1-6 have been detected in several types of chemosynthetic microbial mats and streamers in Nakabusa (29). However, the relative abundance of the 16S rRNA gene sequence of strain 1-6 in these environmental samples was low, representing only $0.2-0.6 \%$ of the total reads in the microbial mat and streamer samples. The 16S rRNA gene sequence of strain 2-18 was not detected in amplicon analyses; however, the presence of strain 2-18 in the communities in Nakabusa was shown by the detection of its putative nifH gene as described above (the relative abundance of the $16 \mathrm{~S}$ rRNA gene sequence was $<0.05 \%$ ) (Fig. 3). The detection of both strains in environmental samples confirmed the presence of these bacteria in their natural habitat. One possible reason for the differences in the abundance of these two strains is their $\mathrm{O}_{2}$ preference. Strain 1-6 preferably grew at $10 \%$ vol. $\mathrm{O}_{2}$ atmosphere, while strain 2-18 preferred lower $\mathrm{O}_{2}$ concentrations of approx. 5\% vol., being inhibited by higher concentrations (Fig. 6).

The effects of molybdate on nitrogen fixation were not observed in the presence of both $\mathrm{H}_{2}$ and thiosulfate at $5 \%$ vol. $\mathrm{O}_{2}$ (Fig. 7a and b). These results indicated that the inhibitory effects of molybdate were not directly related to nitrogenase. The decrease that occurred in nitrogenase activity following the addition of molybdate suggested that the energy acquisition process for nitrogen fixation was inhibited. Molybdate is known to inhibit sulfate reduction as well as thiosulfate disproportionation $(5,17)$. It interferes with the initial step in sulfate reduction, the formation of adenosine-5-phosphosulfate (APS), and the reverse reaction in disproportionation $(5,32)$. The inhibitory effects of molybdate on the nitrogenase activities of strains 1-6 and 2-18 in the absence of $\mathrm{H}_{2}$ and $\mathrm{O}_{2}$ indicates the ability for thiosulfate disproportionation in these Aquificae isolates, similar to previously reported molybdate inhibition in thiosulfate-disproportionating Deltaproteobacteria $(5,17)$. In the presence of $\mathrm{H}_{2}$ and $\mathrm{O}_{2}$ with the addition of molybdate, these bacterial strains harness energy for nitrogen fixation by aerobic hydrogen oxidation (Fig. 7a). Strains 1-6 and 2-18 exhibited the ability to grow under hydrogen-oxidizing conditions, as observed for other bacterial species in the phylum Aquificae (10). Future studies will elucidate thiosulfate metabolism in these isolates underlying the observed molybdate inhibition.

As shown in our previous study (28), the anaerobic nitrogenase activities of chemosynthetic microbial communities in Nakabusa depended on $\mathrm{H}_{2}, \mathrm{CO}_{2}$, and sulfate, and were markedly inhibited by molybdate, which was interpreted as an indication for the sulfate-reducing chemoautotrophic metabolism of the dominating diazotrophs. Although molybdatesensitive nitrogenase activity was observed for the new isolates, the metabolic basis of inhibition appears to differ from previous findings obtained in environmental communities. Sensitivity to molybdate in the isolates was dependent on the absence of $\mathrm{H}_{2}$ and $\mathrm{O}_{2}$, whereas $\mathrm{H}_{2}$ production occurred in environmental communities during incubations (data not shown). The presence of diazotrophic and autotrophic sulfate-reducing members in the thermophilic communities at Nakabusa hot springs cannot be excluded based on the data obtained, and further studies are needed to answer this question.

Nitrogen fixation in Hydrogenobacter strains appears to require semi-aerobic conditions with lower $\mathrm{O}_{2}$ concentrations 
than atmospheric $\mathrm{O}_{2}$ concentrations, in addition to reduced sulfur compounds and/or hydrogen as electron sources. Therefore, microbial mats and streamers appear to be appropriate environments for nitrogen fixation, i.e., the low $\mathrm{O}_{2}$ concentration achieved by $\mathrm{O}_{2}$ consumption through aerobic respiration, anaerobic sulfide production, sulfide supply from hot spring water, elemental sulfur production by abiotic or biotic processes, and hydrogen production by fermentative bacteria $(28,29$, 44). Hydrogenobacter species have been shown to widely populate neutral to alkaline environments at a temperature range higher than $70^{\circ} \mathrm{C}$, at which nitrogen compounds are limited, and some may be capable of fixing and supplying nitrogen in these communities $(3,7,8,22,29,41)$.

\section{Acknowledgements}

We are grateful to Mr. Takahito Momose, the president of Nakabusa Onsen Inn Inc., for allowing us to use their hot springs. We also thank Dr. Shigeki Ehira for helping the nitrogenase activity measurements, Dr. Satoshi Nakagawa for advising on isolation experiments, and Dr. Hiroyuki Arai for kindly providing the bacterial strain, Hydrogenobacter thermophilus TK-6. V.T. and M.T. are funded members of the Photosynthetic Microbial Consortia Laboratory donated by The Institute of Fermentation, Osaka for the term of 2015-2021.

\section{References}

1. Alcamán, M.E., C. Fernandez, A. Delgado, B. Bergman, and B. Díez. 2015. The cyanobacterium Mastigocladus fulfills the nitrogen demand of a terrestrial hot spring microbial mat. ISME J. 9:2290-2303.

2. Boyd, E.S., W.D. Leavitt, and G.G. Geesey. 2009. $\mathrm{CO}_{2}$ uptake and fixation by a thermoacidophilic microbial community attached to precipitated sulfur in a geothermal spring. Appl. Environ. Microbiol. 75:4289-4296.

3. Boyd, E.S., and J.W. Peters. 2013. New insights into the evolutionary history of biological nitrogen fixation. Front. Microbiol. 4:201.

4. Ferrera, I., S. Longhorn, A.B. Banta, Y. Liu, D. Preston, and A.L. Reysenbach. 2007. Diversity of 16 S rRNA gene, ITS region and $a c l B$ gene of the Aquificales. Extremophiles 11:57-64.

5. Finster, K., W. Liesack, and B. Thamdrup. 1998. Elemental sulfur and thiosulfate disproportionation by Desulfocapsa sulfoexigens sp. nov., a new anaerobic bacterium isolated from marine surface sediment. Appl. Environ. Microbiol. 64:119-125.

6. Garten, B., A. Waberski, H. Vo, B.J. Tindall, and M. Thomm. 2001. Hydrogenothermus marinus gen. nov., sp. nov., a novel thermophilic hydrogen-oxidizing bacterium, recognition of Calderobacterium hydrogenophilum as a member of the genus Hydrogenobacter and proposal of the reclassification of Hydrogenobacter acidophilus as Hydrogenobaculum acidophilum gen. nov., comb. nov., in the phylum 'Hydrogenobacter/Aquifex'. Int. J. Syst. Evol. Microbiol. 51:18531862.

7. Hamilton, T.L., E.S. Boyd, and J.W. Peters. 2011. Environmental constraints underpin the distribution and phylogenetic diversity of nifH in the Yellowstone geothermal complex. Microb. Ecol. 61:860870.

8. Hamilton, T.L., E. Koonce, A. Howells, J.R. Havig, T. Jewell, J.R. de la Torre, J.W. Peters, and E.S. Boyd. 2014. Competition for ammonia influences the structure of chemotrophic communities in geothermal springs. Appl. Environ. Microbiol. 80:653-661.

9. Howard, J.B., R. Davis, B. Moldenhauer, V.L. Cash, and D. Dean. 1989. Fe:S cluster ligands are the only cysteines required for nitrogenase Fe-protein activities. J. Biol. Chem. 264:11270-11274.

10. Huber, R., and W. Eder. 2006. Aquificales, p. 925-938. In M. Dworkin, S. Falkow, E. Rosenberg, K.-H. Schleifer, and E. Stackebrandt (ed.), The Prokaryotes, Proteobacteria: Delta, Epsilon Subclass, vol. 7. Springer, New York.

11. Ishii, M., Y. Igarashi, and T. Kodama. 1987. Colony formation of Hydrogenobacter thermophilus on a plate solidified with gelrite. Agric. Biol. Chem. 51:3139-3141.
12. Kato, K., T. Kobayashi, H. Yamamoto, T. Nakagawa, Y. Maki, and T. Hoaki. 2004. Microbial mat boundaries between chemolithotrophs and phototrophs in geothermal hot spring effluents. Geomicrobiol. J. 21:91-98.

13. Kato, S., S. Sakai, M. Hirai, E. Tasumi, M. Nishizawa, K. Suzuki, and K. Takai. 2018. Long-term cultivation and metagenomics reveal ecophysiology of previously uncultivated thermophiles involved in biogeochemical nitrogen cycle. Microbes Environ. 33:107-110.

14. Kawasumi, T., Y. Igarashi, T. Kodama, and M. Yasuji. 1984. Hydrogenobacter thermophilus gen. nov., sp. nov., an extremely thermophilic, aerobic, hydrogen-oxidizing bacterium. Int. J. Syst. Bacteriol. 34:5-10.

15. Kimura, H., K. Mori, H. Nashimoto, S. Hanada, and K. Kato. 2010. In situ biomass production of a hot spring sulfur-turf microbial mat. Microbes Environ. 25:140-143.

16. Kimura, H., K. Mori, H. Nashimoto, S. Hattori, K. Yamada, K. Koba, N. Yoshida, and K. Kato. 2010. Biomass production and energy source of thermophiles in a Japanese alkaline geothermal pool. Environ. Microbiol. 12:480-489.

17. Krämer, M., and H. Cypionka. 1989. Sulfate formation via ATP sulfurylase in thiosulfate- and sulfite-disproportionating bacteria. Arch. Microbiol. 151:232-237.

18. Kryukov, V.R., N.D. Savelyeva, and M.A. Pusheva. 1983. Calderobacterium hydrogenophilum nov. gen., nov. sp., an extreme thermophilic hydrogen bacterium, and its hydrogenase activity. Mikrobiologiya 52:781-788.

19. Kumar, S., G. Stecher, and K. Tamura. 2016. MEGA7: molecular evolutionary genetics analysis version 7.0 for bigger datasets. Mol. Biol. Evol. 33:1870-1874.

20. Lane, D.J., B. Pace, G.J. Olsen, D.A. Stahl, M.L. Sogin, and N.R. Pace. 1985. Rapid determination of 16 S ribosomal RNA sequences for phylogenetic analyses. Proc. Natl. Acad. Sci. U.S.A. 82:6955-6959.

21. Lane, D.J. 1991. 16S/23S rRNA sequencing, p. 115-147. In E. Stackebrandt and M. Goodfellow (ed.), Nucleic Acid Techniques in Bacterial Systematics. John Wiley \& Sons, Chichester.

22. Loiacono, S.T., D.R. Meyer-Dombard, J.R. Havig, A.T. Poret-Peterson, H.E. Hartnett, and E.L. Shock. 2012. Evidence for high-temperature in situ nifH transcription in an alkaline hot spring of Lower Geyser Basin, Yellowstone National Park. Environ. Microbiol. 14:1272-1283.

23. Ludwig, W., O. Strunk, R. Westram, et al. 2004. ARB: a software environment for sequence data. Nucleic Acids Res. 32:1363-1371.

24. Merkel, A.Y., N.V. Pimenov, I.I. Rusanov, et al. 2017. Microbial diversity and autotrophic activity in Kamchatka hot springs. Extremophiles 21:307-317.

25. Meyer-Dombard, D.R., W. Swingley, J. Raymond, J. Havig, E.L. Shock, and R.E. Summons. 2011. Hydrothermal ecotones and streamer biofilm communities in the Lower Geyser Basin, Yellowstone National Park. Environ. Microbiol. 13:2216-2231.

26. Nakagawa, T., and M. Fukui. 2002. Phylogenetic characterization of microbial mats and streamers from a Japanese alkaline hot spring with a thermal gradient. J. Gen. Appl. Microbiol. 48:211-222.

27. Nakagawa, T., and M. Fukui. 2003. Molecular characterization of community structures and sulfur metabolism within microbial streamers in Japanese hot springs. Appl. Environ. Microbiol. 69:7044-7057.

28. Nishihara, A., S. Haruta, S.E. McGlynn, V. Thiel, and K. Matsuura. 2018. Nitrogen fixation in thermophilic chemosynthetic microbial communities depending on hydrogen, sulfate, and carbon dioxide. Microbes Environ. 33:10-18.

29. Nishihara, A., V. Thiel, K. Matsuura, S.E. McGlynn, and S. Haruta. 2018. Phylogenetic diversity of nitrogenase reductase genes and possible nitrogen-fixing bacteria in thermophilic chemosynthetic microbial communities in Nakabusa hot springs. Microbes Environ. 33:357-365.

30. Noll, M., D. Matthies, P. Frenzel, M. Derakshani, and W. Liesack. 2005. Succession of bacterial community structure and diversity in a paddy soil oxygen gradient. Environ. Microbiol. 7:382-395.

31. Nunoura, T., H. Oida, M. Miyazaki, and Y. Suzuki. 2008. Thermosulfidibacter takaii gen. nov., sp. nov., a thermophilic, hydrogenoxidizing, sulfur-reducing chemolithoautotroph isolated from a deepsea hydrothermal field in the Southern Okinawa Trough. Int. J. Syst. Evol. Microbiol. 58:659-665.

32. Peck, H.D. 1959. The ATP-dependent reduction of sulfate with hydrogen in extracts of Desulfovibrio desulfuricans. Proc. Natl. Acad. Sci. U.S.A. 45:701-708. 
33. Poly, F., L.J. Monrozier, and R. Bally. 2001. Improvement in the RFLP procedure for studying the diversity of nifH genes in communities of nitrogen fixers in soil. Res. Microbiol. 152:95-103.

34. Purcell, D., U. Sompong, L.C. Yim, T.G. Barraclough, Y. Peerapornpisal, and S.B. Pointing. 2007. The effects of temperature, $\mathrm{pH}$ and sulphide on the community structure of hyperthermophilic streamers in hot springs of northern Thailand. FEMS Microbiol. Ecol. 60:456-466.

35. Sahm, K., P. John, H. Nacke, B. Wemheuer, R. Grote, R. Daniel, and G. Antranikian. 2013. High abundance of heterotrophic prokaryotes in hydrothermal springs of the Azores as revealed by a network of $16 \mathrm{~S}$ rRNA gene-based methods. Extremophiles 17:649-662.

36. Siering, P.L., G. V. Wolfe, M.S. Wilson, et al. 2013. Microbial biogeochemistry of boiling springs lake: a physically dynamic, oligotrophic, low-pH geothermal ecosystem. Geobiology 11:356-376.

37. Steunou, A.S., S.I. Jensen, E. Brecht, et al. 2008. Regulation of nif gene expression and the energetics of $\mathrm{N}_{2}$ fixation over the diel cycle in a hot spring microbial mat. ISME J. 2:364-378.

38. Steunou, A.S., D. Bhaya, M.M. Bateson, et al. 2006. In situ analysis of nitrogen fixation and metabolic switching in unicellular thermophilic cyanobacteria inhabiting hot spring microbial mats. Proc. Natl. Acad. Sci. U.S.A. 103:2398-2403.

39. Stewart, W.D.P., G.P. Fitzgerald, and R.H. Burris. 1967. In situ studies on $\mathrm{N}_{2}$ fixation using the acetylene reduction technique. Proc. Natl. Acad. Sci. U.S.A. 58:2071-2078.

40. Takacs, C.D., M. Ehringer, R. Favre, M. Cermola, G. Eggertsson, A. Palsdottir, and A.L. Reysenbach. 2001. Phylogenetic characterization of the blue filamentous bacterial community from an Icelandic geothermal spring. FEMS Microbiol. Ecol. 35:123-128.
41. Takacs-Vesbach, C., W.P. Inskeep, Z.J. Jay, et al. 2013. Metagenome sequence analysis of filamentous microbial communities obtained from geochemically distinct geothermal channels reveals specialization of three Aquificales lineages. Front. Microbiol. 4:84.

42. Takai, K., T. Komatsu, and K. Horikoshi. 2001. Hydrogenobacter subterraneus sp. nov., an extremely thermophilic, heterotrophic bacterium unable to grow on hydrogen gas, from deep subsurface geothermal water. Int. J. Syst. Evol. Microbiol. 51:1425-1435.

43. Tamazawa, S., K. Takasaki, H. Tamaki, Y. Kamagata, and S. Hanada. 2012. Metagenomic and biochemical characterizations of sulfur oxidation metabolism in uncultured large sausage-shaped bacterium in hot spring microbial mats. PLoS One 7:e49793.

44. Tamazawa, S., K. Yamamoto, K. Takasaki, Y. Mitani, S. Hanada, Y. Kamagata, and H. Tamaki. 2016. In situ gene expression responsible for sulfide oxidation and $\mathrm{CO}_{2}$ fixation of an uncultured large sausageshaped Aquificae bacterium in a sulfidic hot spring. Microbes Environ. 31:194-198.

45. Wirth, R., J. Sikorski, E. Brambilla, et al. 2010. Complete genome sequence of Thermocrinis albus type strain (HI 11/12 $)$. Stand. Genomic Sci. 2:194-202.

46. Yim, L.C., J. Hongmei, J.C. Aitchison, and S.B. Pointing. 2006. Highly diverse community structure in a remote central Tibetan geothermal spring does not display monotonic variation to thermal stress. FEMS Microbiol. Ecol. 57:80-91.

47. Zehr, J.P., B.D. Jenkins, S.M. Short, and G.F. Steward. 2003. Nitrogenase gene diversity and microbial community structure: a cross-system comparison. Environ. Microbiol. 5:539-554.

48. Zeytun, A., J. Sikorski, M. Nolan, et al. 2011. Complete genome sequence of Hydrogenobacter thermophilus type strain (TK-6 ${ }^{\mathrm{T}}$ ). Stand. Genomic Sci. 4:131-143. 